\title{
PENGARUH KOMPETENSI DAN DISIPLIN KERJA TERHADAP KINERJA PEGAWAI PADA DINAS PERHUBUNGAN KABUPATEN LAMPUNG SELATAN
}

\author{
Kuswarak \\ Fakultas Ekonomi, Universitas Sang Bumi Ruwa Jurai Bandar Lampung
}

\section{ABSTRACT}

Work discipline is very necessary to be applied to a government institution. Because by applying the provisions set by the organization whose form of regulation will direct employees to act according to the wishes of the organization. The purpose of this study is to find out the Effect of Work Discipline and Work Competence on Employee Performance at the South Lampung District Transportation Service to the population as respondents. Methods of collecting data as primary data through observation, interview and questionnaire and secondary data.

Based on the regression equation the results of hypothesis testing have proven that there is an influence between work discipline and employee performance. testing the work motivation hypothesis shows the value of $t$ count of -0.243 with a significance level of 0.720 . The significance level is greater than 0.05 , which means that the hypothesis in this study accepts $\mathrm{Ho}$ and rejects $\mathrm{Ha}$. Thus it can mean that the $\mathrm{H} 1$ hypothesis "work discipline" does not have a positive influence on Employee Performance "rejected.

The results of hypothesis testing have proven that there is an influence between work motivation and employee performance. The test proves that the results of testing the work motivation hypothesis show the value of $t$ count of 4.505 with a significance level of 0,000. The significance level of the result of 0,000 is smaller than 0.05, which means that the hypothesis in this study accepts Ha and rejects $\mathrm{Ho}$. Thus it can mean that the $\mathrm{H} 2$ hypothesis "work motivation has a positive effect on employee performance" is accepted.

Keywords: Work Competence, Work Motivation, Employee Performance

\section{PENDAHULUAN}

\subsection{Latar Belakang}

Beberapa tahun terakhir konsep kompetensi ini mulai memfokuskan pada hubungan antaraorang dan pekerjaan yang oleh beberapa peneliti telah ditemukan adanyahubungan ketika mengidentifikasi gambaran pengetahuan dan ketrampilan pokoksaat bekerja (Sandberg, 2008:96). Suatu lembaga bukan hanya membutuhkan kompetensi dari karyawan atau anggotanya, melainkan juga suatu sikap disiplin. Sebab apabila anggota suatu organisasi dapat mendisiplinkan dirinya, maka tidak disanksikan lagi organisasi tersebut dapat berjalan dengan baik.

Disiplin merupakan perasaan taat dan patuh terhadap pekerjaan yang menjadi tanggung jawab. Disiplin ini berhubungan erat dengan wewenang. Apabila wewenang tidak berjalan dengan semestinya, maka disiplin akan hilang. Oleh karena ini, pemegang wewenang harus dapat menanamkan disiplin terhadap dirinya sendiri sehingga mempunyai tanggung jawab terhadap pekerjaan sesuai dengan wewenang yang ada padanya.

Dinas Perhubungan Kabupaten Lampung Selatan merupakan lembaga pemerintah yang mengemban tugas memberikan pelayanan terutama dalam bidang perhubungan, baik hubungan yang berkaitan dengan kegiatan di darat ataupun di udara hingga laut. Untuk mencapai target pada bentuk pelayanan tersebut tentunya dibutuhkan arahan kerja yang didukung oleh adanya kompetensi dan disiplin agar karyawan selaku pegawai negeri dapat bekerja dengan baik dan memberikan keluaran (outcome) yang sesuai dengan arah kebijakan sebagaimana tertuang dalam rencana strategis dinas. 
Begitu juga dengan upaya menandatangani SKP bawahan, memberikan peringatan kepada bawahan terkait dengan pelanggaran disiplin sesuai dengan peraturan perundang-undangan masih terkesan subjektif dan kekeluargaan. Selain itu juga tentang Kedinasan, Rencana Kerja Anggaran, Perlengkapan Barang Dinas, Rancangan akhir LKPD, KUA / PPAS, Rancangan akhir RPJMD dan LPPD, Rancangan akhir LAKIP Dinas dan Rancangan akhir RKPD adalah elemen yang harus diketahui dan dikuasai oleh karyawan. Namun terhadap hal tersebut, ada sebagain karyawan yang kurang memahami secara utuh tentang pelaporan pengelolaan keuangan dinas, rancangan hasil tindak lanjut tugas-tugas lain sehingga scara manajemen perlu adanya peningkatan prestasi kerja melalui kompetensi dengan tujuan meningkatnya disiplin kepegawaian dan juga kinerja. Kemudian masih ada beberapa karyawan yang bekerja tanpa prosedur kerja sekalipun telah tersedia SOP (Sistem Operasional Prosedur) terutama dalam pelayanan administrasi perkantoran.

Berdasarkan alur kerja sebagaimana digambarkan dan diarahkan oleh bagian sekretariat tentang kepegawaian, permasalahan yang muncul di lingkungan Dinas Perhubungan Kabupaten Lampung Selatan berkaitan dengan karyawan dalam menyelesaikan beban kerja adalah yang berhubungan dengan kepatuhan termasuk kehadiran karyawan. Adapun kehadiran karyawan pada Kantor Dinas Perhubungan Kabupaten Lampung Selatan dapat dilihat pada tabel berikut:

Tabel 1.

Tingkat Kehadiran Karyawan Dinas Perhubungan Kabupaten Lampung Selatan

\begin{tabular}{cccc}
\hline Bulan & Laki-Laki & Perempuan & Keterangan \\
\hline Juli & 4 & 6 & Sakit dan Keperluan Keluarga \\
\hline Agustus & 12 & 4 & Sakit dan Keperluan Keluarga \\
\hline September & 4 & 14 & Sakit dan Keperluan Keluarga \\
\hline Jumlah & 8 & 13 & \\
\hline
\end{tabular}

Sumber: $\quad$ Data diolah, 2016

Berdasarkan tabel 1 di atas, tingkat kehadiran karyawan Dinas Perhubungan Kabupaten Lampung Selatan dari 72 orang karyawan sebagian besar dalam satu bulannya terdapat karyawan yang tidak hadir. Pada bulan Juli 2016 terdapat ketidak hadiran karyawan sebanyak 4 orang karyawan laki-laki dan 6 orang karyawan perempuan. Pada bulan Agustus terdapat ketidak hadiran karyawan sebanyak 12 orang karyawan laki-laki dan 4 orang karyawan perempuan dan pada bulan September terdapat ketidak hadiran karyawan sebanyak 4 orang karyawan laki-laki dan 14 orang karyawan perempuan. Ketidakhadiran para karyawan selalu dilengkapi dengan surat keterangan sakit dari dokter dan yang untuk keperluan keluarga mereka melakukan penulisan surat keterangan tidak hadir.

\subsection{Perumusan Masalah}

1. Apakah kompetensi berpengaruh terhadap kinerja pegawai pada Dinas Perhubungan Kabupaten Lampung Selatan?

2. Apakah disiplin kerja berpengaruh terhadap kinerja pegawai pada dinas Perhubungan Kabupaten Lampung Selatan?

3. Apakah kompetensi dan disiplin kerja secara bersama-sama berpengaruh terhadap kinerja pegawai pada Dinas Perhubungan Kabupaten Lampung Selatan?

\subsection{Tujuan Penelitian}

Penelitian ini bertujuan ingin mengetahui :

1. Pengaruh kompetensi terhadap kinerja pegawai pada Dinas Perhubungan Kabupaten Lampung Selatan. 


\section{Kuswarak}

2. Pengaruh disiplin kerja terhadap kinerja pegawai pada Dinas Perhubungan Kabupaten Lampung Selatan.

3. Pengaruh kompetensi dan disiplin kerja secara bersama-sama terhadap kinerja pegawai pada Dinas Perhubungan Kabupaten Lampung Selatan.

\section{TINJAUAN PUSTAKA}

\subsection{Kompetensi Pegawai}

Kompetensi merujuk kepada karakteristik yang mendasari perilaku yang menggambarkan motif, karakteristik pribadi (ciri khas), konsep diri, nilai-nilai, pengetahuan atau keahlian yang dibawa seseorang yang berkinerja unggul (superior performer) di tempat kerja. Kompetensi adalah mengenai orang seperti apa dan apa yang dapat mereka lakukan, bukan apa yang mungkin mereka lakukan.

Kompetensi ditemukan pada orangorang yang diklasifikasikan sebagai berkinerja unggul atau efektif.R. Palan, (2007:167), menyatakan bahwa kompetensi memiliki definisi yang beragam, namun definisi yang layak diterima adalah bahwa kompetensi didefinisikan sebagai karakteristik dasar seseorang yang memiliki hubungan kausal dengan kriteria referensi efektivitas dan/atau keunggulan dalam pekerjaan atau situasi tertentu. Terdapat lima jenis karakteristik kompetensi, yaitu:

1. Pengetahuan, merujuk pada informasi dan hasil pembelajaran.

2. Keterampilan, merujuk pada kemampuan seseorang untuk melakukan suatu kegiatan.

3. Konsep diri dan nilai-nilai, merujuk pada sikap, nilai-nilai dan citra diri seseorang.

4. Karakteristik Pribadi, merujuk pada karakteristik fisik dan konsistensi tanggapan terhadap situasi atau informasi.

5. Motif, merupakan motivasi, hasrat, kebutuhan psikologis, atau dorongandorongan lain yang memicu tindakan.

McCleland memperkenalkan istilah kompetensi dalam makalahnya yangberjudul Testing for Competence rather than Intelligence. Pada makalah tersebutMcCleland menyimpulkan bahwa test prestasi akademik tradisional dan testpengetahuan seperti kelulusan sekolah dan ijazah (Spencer and Spencer, 2003:89):

1. Tidak dapat mempredikasi kinerja pada suatu pekerjaan atau kesuksesan dalam kehidupan.

2. Sering ditemui bias akibat pengaruh minoritas, perempuan dan orang-orang yang berasal dari strata sosial ekonomi bawah.

Ansorena dan Levy-Leboyer (dalam Agut dan Grau, 2002) pandangannya mengemukakan bahwa konsep kompetensi terdiri atas dua dimensi masing-masing adalah technical competency dan generic competency. Kompetensi teknis atau technical competency adalah kompetensi yang berupa pengetahuan, ketrampilan dan kemampuan (KSA's) yang pada dasarnya terdiri atas penguasaan pengetahuan tentang suatu topik dan bagaimana cara menerapkannya dalam suatutugas sehingga menghasilkan kinerja yang efisien pada tugas tersebut, dimana KSA's tersebut sebagian besar bersifat rutin, terprogram dan teknis.

Pada sisi lain kompetensi yang meliputi karakteristik individu (misalnya motivasi, sikap atau ciri-ciri kepribadian) yang mempengaruhi secara tidak rutin, tidak terprogram danbukan tugas teknis tetapi juga merupakan bagian dari tugas diistilahkan sebagai kompetensi umum atau generic competency. Kompetensi ini dapat berlaku umum bagi seluruh organisasi dan diterapkan pada seluruh staf atau diterapkan pada sekelompok jabatan sejenis atau jabatan yang saling berhubungan dimana karakteristik pekerjaannya hampir sama meskipun tingkatanya berbeda atau dapat melingkupi juga suatu kedudukan misalnya manajer, ilmuwan, staf profesional, staf penjualan (Amstrong 1999; Agut dan Grau, 2002:53).

\subsection{Pengertian Disiplin Pegawai}

Pegawai negeri dalam memberikan pelayanan kepada masyarakat harus memiliki disiplin diri terutama dalam menyelesaikan beban kerja, sebab apabila disiplin kerja telah terpenuhi, dipastikan lembaga atau dinas yang 
berhubungan langsung dengan pelaksanaan beban kerja ini akan meningkatkan kinerja yang sangat dibutuhkan oleh suatu daerah dalam memanfaatkan potensi daerah. Selain itu juga apabila disiplin kerja pada suatu lembaga telah berjalan dengan baik dan benar, maka dipastikan akan menghasilkan suatu kinerja yang ditunjukan dengan adanya prestasi kerja.

Sebab dengan adanya disiplin kerja akan melahirkan suatu target dalam hal ini kinerja pegawai yang dikaitkan dengan disiplin kerja. Ketentuan yang ditetapkan oleh organisasi yang bentuknya peraturan diharapkan pegawai dapat berbuat sesuai dengan keinginan organisasi. Peraturan yang dibuat dimaksudkan untuk mengatur seluruh kegiatan pegawai dan aturan tersebut harus mengikat serta adanya sanksi yang jelas dan tegas untuk mendorong pegawai bekerja untuk dijadikan berdisiplin dalam bekerja. Sehingga kedisplinan merupakan kesadaran kesediaan mentaati semua peraturan organisasi dan norma-norma sosial yang berlaku diantaranya selalu datang dan pulang tepat pada waktunya, mengerjakan semua pekerjaannya dengan secara baik (Fathoni, 2006 : 172)

Penerapan disiplin kerja di lingkungan kerja, memang awalnya akan dirasakan berat oleh para pegawai, tetapi apabila terus menerus diberlakukan akan menjadi kebiasaan, dan disiplin tidak akan menjadi beban berat bagi para pegawai. Disiplin ini perlu diterapkan di lingkungan kerja, karena seperti telah disinggung di atas bahwa disiplin tidak lahir begitu saja, tetapi perlu adanya pembinaanpembinaan dalam menegakkan disiplin kerja ini. Sehubungan dengan itu, bagaimana mewujudkan disiplin kerja yang baik dalam organisasi.

Selanjutnya Maryoto (2001: 98) mengatakan bahwa: "Pimpinan dalam pembinaan disiplin terhadap bawahan harus memperhatikan : pengawasan yang berkelanjutan, mengetahui organisasi yang dipimpinnya, instruksi harus jelas dan tegas tidak membingungkan bawahan. Menurut prosedur kerja yang sederhana dan mudah dipahami, membuat kegiatan yang dapat menyibukkan anak buah".
Disamping itu untuk pembinaan telah ditetapkan dalam Peraturan Pemerintah No 53 tahun 2010 tentang Disiplin Pegawai Negeri Sipil, disebutkan ada tiga tingkatan dan jenis hukuman disiplin pada pegawai negeri sipil. Hukuman disiplin terdiri dari 1) Hukuman disiplin ringan, 2) Hukuman disiplin sedang, dan 3) Hukuman disiplin berat.

\subsection{Kinerja Karyawan}

Kinerja dapat diartikan sebagai prestasi yang dicapai karyawan dalam melaksanakan suatu pekerjaan pada suatu organisasi. Agar dapat memberikan umpan balik bagi karyawan maupun organisasi, maka perlu dilakukan penilaian atas prestasi tersebut (Handoko, 2001). Sedangkan pengertian tentang prestasi kerja (job performance) menurut Lawer dan Porter (As'ad, 2002) ialah successful role achievement yang diperoleh seseorang dari perbuatannya.

Pengertian lain, kinerja adalah aktifitas atau kegiatan untuk melakukan atau menyelenggarakan tugas tertentu mengacu pada satu aturan tugas yang ditetapkan. Untuk menciptakan suatu kinerja yang baik diperlukan adanya koordinasi antara unit-unit pimpinan atau manager (Sumarlin, 2003). Menurut Subagyo (1977) dalam Silalahi (2005), kinerja merupakan kemampuan seseorang dalam melaksanakan tugas atau pekerjaan secara cepat dan tepat sesuai dengan aturan yang berlaku, teratur dan sesuai dengan prosedur kerja serta berkesinambungan yang didukung dengan tingginya bertanggung jawab menurut Malayu S.Hasibuan dalam Anwar P.Mangkunegara (2006:17) aspek-aspek yang dinilai dalam kinerja mencakup sebagai berikut

1. Prestasi kerja, yakni hasil kerja yang dicapai dalam melaksanakan tugas yang diberikan kepadanya yang dipengaruhi oleh kecakapan, pengalaman dan kesungguhan

2. Tanggung jawab, adalah kesanggupan pegawai dalam melaksanakan pekerjaan yang diserahkan kepadanya dengan sebaik-baiknya dan tepat waktu, serta berani memikil resiko atas keputusan yang diambil 


\section{Kuswarak}

3. Ketaatan, adalah kesanggupan seorang pegawai untuk mentaati segala peraturan perundang-undangan dan kedinasan yang berlaku

4. Kejujuran, adalah ketulusan hati seseorang pegawai dalam melaksanakan tugas dan kemampuan untuk tidak menyalahgunakan wewenang

5. Kerjasama, adalah kemampuan seseorang pegawai untuk bekerjasama dengan orang lain dalam menyelesaikan tugas yang diberikan sehingga mencapai daya guna dan hasil guna secara optimal.

Penilaian kinerja (performance appraisal) pada dasarnya merupakan faktor kunci guna mengembangkan suatu organisasi secara efektif dan efisien, karena adanya kebijakan atau program yang lebih baik atas sumber daya manusia yang ada dalam organisasi.

Berdasarkan beberapa pendapat tentang penilaian kinerja yang dapat dijadikan sebagai acuan guna mengukur atau menilai kinerja karyawan, yakni :

1. Faktor kualitas kerja, yang dapat dilihat dari segi ketelitian dan kerapihan bekerja.

2. Faktor kekuatan kerja, diukur dari kemampuan secara kuantitatif di dalam mencapai target atau hasil kerja atas pekerjaan-pekerjaan baru.

3. Faktor pengetahuan, mengukur kemampuan kerja karyawan dalam memahami hal-hal yang berkaitan dengan tugas yang mereka lakukan.

4. Faktor keandalan, mengukur kemampuan dan keandalan dalam melaksanakan tugasnya baik dalam menjalankan peraturan maupun kebijakan dan disiplin.

5. Faktor kehadiran, yaitu melihat aktivitas pekerja didalam kegiatan-kegiatan rutin kantor, rapat-rapat atau kehadiran ditengah-tengah masyarakat yang membutuhkannya.

6. Faktor kerjasama, melihat bagaimana karyawan bekerja dengan orang lain dalam menyelesaikan suatu pekerjaan.

\subsection{Hipotesis}

4.1 Kompetensi berpengaruh terhadap kinerja pegawai pada Dinas Perhubungan Kabupaten Lampung Selatan

4.2 Disiplin kerjaber pengaruh terhadap kinerja pegawai pada Dinas Perhubungan Kabupaten Lampung Selatan

4.3 Kompetensi dan disiplin kerja secara bersama-sama berpengaruh terhadap kinerja pegawai pada Dinas Perhubungan Kabupaten Lampung Selatan.

\section{METODOLOGI PENELITIAN}

\subsection{Jenis Penelitian}

Penelitian ini menggunakan pendekatan jenis penelitian kuantitatif dengan jenis penelitian survey metode eksplanatif yaitu suatu metode pemberian penjelasan untuk melihat kaitan antar variabel dan selanjutnya mengambil langkah berupa penjelasanpenjelasan yang mengkaitkan antar variabel tersebut.

\subsection{Variabel Penelitian}

1. Variabel bebas (Independent variable) terdiri dari Kompetensi dan Disiplin kerja. Kompetensi pegawai meliputi karakteristik individu (misalnya motivasi, sikap atau ciriciri kepribadian) berlaku umum bagi seluruh organisasi dan diterapkan pada seluruh staf atau diterapkan pada sekelompok jabatan sejenis atau jabatan yang saling berhubungan.

Displin kerja; Pimpinan dan karyawan Dinas Perhubungan Kabupaten Lampung Selatan harus bertindak disiplin, dimana sebagai variabel bebas dalam penelitian ini merupakan suatu variabel yang mempengaruhi variabel lainnya dan variable bebas yang dipergunakan adalah "Disiplin Kerja" dengan aspek penelaahan tentang kesadaran dan kesediaan mentaati semua peraturan organisasi dan norma-norma sosial yang berlaku, Selalu datang dan pulang tepat pada waktunya dan mengerjakan semua pekerjaannya dengan baik.

2. Variabel Terikat Kinerja Pegawai (Dependent variable); Kinerja dapat tercapai dengan peran pimpinan dan 
karyawan Dinas Perhubungan Kabupaten Lampung Selatan. Sebagaivariabel terikat dalam penelitian ini atau yang merupakan suatu variable yang dipengaruhi oleh variable lainnya dan dalam penelitian ini adalah "kinerja pegawai" dengan aspek pengukuran adalah Prestasi Kerja, Tanggung Jawab, Ketaatan, Kejujuran dan Kerjasama.

\subsection{Populasi dan Sampel}

Dalam penelitian ini akan melakukan teknik pengambilan populasi yaitu pengambilan suatu data sampel yang diambil secara keseluruhan kepada para karyawan Dinas Perhubungan Kabupaten Lampung Selatan sehingga masing-masing mendapat kesempatan sebagai sampel untuk memperoleh data yang dibutuhkan. Untuk mendukung penelitian ini, penulis merujuk pendapat (Suharsimi Arikunto, 2000 : 107), yang menyatakan apabila dalam suatu penelitian terhadap subjek yang kurang dari 100, maka populasi akan diambil seluruhnya sebagai sampel. Sedangkan apabila subjek lebih dari 100, maka sampel yang diambil antara $10 \%-15 \%$ atau $20 \%-25 \%$ dari seluruh populasi yang ada. Dikarenakan dalam penelitian ini subjeknya adalah para Karyawan Dinas Perhubungan Kabupaten Lampung Selatan yang jumlahnya 72 orang maka penelitian ini adalah penelitian Populasi dengan jumlah responden seluruhnya yang akan diteliti adalah 72 orang.

\subsection{Metode Pengumpulan Data}

1. Data Primer, yaitu data yang dikumpulkan dari Dinas Perhubungan Kabupaten Lampung Selatan. Metode ini adalah suatu tinjauan langsung (field research)

2. Data Skunder, yaitu data penunjang yang diperoleh dengan cara mengumpulkan sumber data, baik dari literatur, majalah, buku-buku yang menunjang penelitian ini.

\subsection{Metode Analisis Data}

\section{Analisis Kuantitatif}

Untuk mengetahui pengaruh kompetensi pegawai dan disiplin kerja terhadap kinerja pegawai pada Dinas Perhubungan
Kabupaten Lampung Selatan, maka analisis yang digunakan menggunakan rumus statistis Regresi linear berganda, dengan persamaan garis regresi yaitu $Y=a+b_{1} X_{1}+b_{2} X_{2}+$ et

\section{Analisis Determinasi Parsial dan Berganda.}

Bentuk dari model yang akan digunakan (Riduan, 2009 : 87) sebagai berikut:

1. Untuk mengetahui Pengaruh Kompetensi (variabel $X_{1}$ ) terhadap kinerja pegawai (variabel $Y$ ) di gunakan rumus:

$$
r_{x_{1} y}^{2}=\frac{\left\{n\left(\Sigma X_{1} Y\right)-\left(\Sigma X_{1}\right)(\Sigma Y)\right\}^{2}}{\left.\left\{n\left(\Sigma X_{1}^{2}\right)-\left(\Sigma X_{1}\right)^{2}\right\} n\left(\Sigma Y^{2}\right)-(\Sigma Y)^{2}\right\}}
$$

2. Untuk mengetahui Disiplin Kerja (variabel $\mathrm{X}_{2}$ ) terhadap kinerja pegawai (variabel $\mathrm{Y}$ ) digunakan rumus:

$$
r_{x_{2} y}^{2}=\frac{\left\{n\left(\Sigma X_{2} Y\right)-\left(\Sigma X_{2}\right)(\Sigma Y)\right\}^{2}}{\left\{n\left(\Sigma X_{2}{ }^{2}\right)-\left(\Sigma X_{2}\right)^{2}\right\}\left\{n\left(\Sigma Y^{2}\right)-(\Sigma Y)^{2}\right\}}
$$

3. Untuk mengetahui pengaruh kompetensi (variabel $X_{1}$ ) dan disiplin kerja (variabel $X_{2}$ ) secara bersama-sama terhadap kinerja kegawai (variabel $\mathrm{Y}$ ) di gunakan rumus:

$$
R_{x_{1} x_{2} y}^{2}=\frac{r_{x_{1} y}^{2}+r_{x_{2} y}^{2}-2\left(r_{x_{1} y}\right)\left(r_{x_{2} y}\right)\left(r_{x_{1} x_{2}}\right)}{1-r_{x_{1} x_{2}}^{2}}
$$

Perhitungan seluruh koefisien determinasi tersebut di atas seluruhnya menggunakan paket program Statistical Product and Service Solution (SPSS.21)

\subsection{Uji Hipotesis.}

Untuk menguji hipotesis pengaruh variabel $X_{1}$, variabel $X_{2}$ terhadap variabel $Y$ secara sendiri-sendiri (parsial) dilakukan pengujian dengan uji-t atau Probabiltas volue ( $\rho$-volue), sedangkan pengujian signifikansi secara bersama sama (simultan) digunakan uji-F atau ( $\rho$-volue) dengan menggunakan tingkat keyakinan $95 \%$ atau dengan menggunakan tingkat signifikan $(\boldsymbol{\alpha})=5 \%$. 


\section{Kuswarak}

Pernyataan Hipotesisnya :

Ho : Tidak ada pengaruh signifikan antara variabel bebas dengan variabel terikat

$\mathrm{Ha}$ : Ada pengaruh Signifikan antara variabel bebas dan variabel terikat

Bila F/t hitung $>$ F/t tabel maka Ho ditolak atau Ha diterima

Atau bila Probabilitas volue ( $\rho$ volue)<tingkat signifikansi (a) 0,05 maka Ho ditolak atau Ha diterima.

\section{ANALISIS DAN PEMBAHASAN}

\subsection{Analisis Data}

Kriteria atau syarat dari suatu model persamaan regresi yang baik adalah yang memenuhi persyaratan asumsi klasik, antara lain semua data berdistribusi normal, model harus bebas dari gejala multikolinieritas dan terbebas dari heterokedastisitas. Dari analisis sebelumnya telah terbukti bahwa model persamaan yang diajukan dalam penelitian ini telah memenuhi persyaratan asumsi klasik sehingga model persamaan dalam penelitian ini sudah dianggap baik. Analisis regresi digunakan untuk menguji hipotesis tentang pengaruh secara parsial variabel bebas terhadap variabel terikat. Berdasarkan estimasi regresi berganda dengan program SPSS 16 diperoleh hasil seperti tabel berikut:

Tabel 2.

Hasil Estimasi Regresi

\begin{tabular}{|c|c|c|c|c|c|c|c|}
\hline \multirow{2}{*}{ Model } & \multicolumn{2}{|c|}{$\begin{array}{l}\text { Unstandardized } \\
\text { Coefficients }\end{array}$} & \multirow{2}{*}{$\begin{array}{c}\begin{array}{c}\text { Standardized } \\
\text { Coefficients }\end{array} \\
\text { Beta }\end{array}$} & \multirow{2}{*}{ t } & \multirow{2}{*}{ Sig. } & \multicolumn{2}{|c|}{ 95\% Confidence Interval } \\
\hline & B & Std. Error & & & & $\begin{array}{l}\text { Lower } \\
\text { Bound }\end{array}$ & $\begin{array}{l}\text { Upper } \\
\text { Bound }\end{array}$ \\
\hline 1 (Constant) & 4,241 & 4,173 & & 1,038 & ,305 & $-4,079$ & 12,740 \\
\hline Kompetensi &,- 088 & ,245 &,- 069 &,- 361 & ,720 &,- 582 & ,405 \\
\hline Disiplin & 950 & 229 & ,793 & 4,155 & .000 & 000 & 1,411 \\
\hline
\end{tabular}

a. Dependent Variable: Kinerja Pegawai Sumber: Lampiran output SPSS

Berdasarkan tabel 1 di atas dapat diketahui persamaan regresi yang terbentuk adalah: $Y=4.241-0,088 X_{1}+0,950 X_{2}$ Dari persamaan tersebut dapat dijelaskan bahwa:

a. Variabel kompetensi, mempunyai arah koefisien yang bertanda negatif terhadap kinerja karyawan. Tetapi kompetensi mempunyai arah koefisien yang bertanda positif terhadap kinerja karyawan.

b. Koefisien kompetensi memberikan nilai sebesar -0,088 yang berarti bahwa jika kompetensi semakin baik dengan asumsi variabel lain tetap maka kinerja akan mengalami penurunan.

c. Koefisien disiplin kerja memberikan nilai sebesar 0,950 yang berarti bahwa jika disiplin kerja semakin tinggi dengan asumsi variabel lain tetap maka kinerja karyawan akan mengalami peningkatan.

\subsection{Pengujian Hipotesis}

Untuk menguji pengaruh variabel bebas secara bersama-sama diuji dengan menggunakan uji F. Hasil perhitungan regresi secara simultan diperoleh hasil pengaruh variabel bebas secara bersama-sama terhadap variabel terikatnya dilakukan dengan menggunakan uji $\mathrm{F}$. Hasil perhitungan statistik menunjukkan nilai $F$ hitung $=25,876$ Dengan menggunakan batas signifikansi 0,05, maka diperoleh nilai signifikansi tersebut lebih besar dari 0,05 . Hal ini berarti bahwa hipotesis yang menyatakan bahwa secara simultan variabel disiplin kerja dan motivasi kerja mempunyai pengaruh terhadap kinerja Pegawai.

\section{Koefisien Determinasi $\left(\mathbf{R}^{2}\right)$}

Koefisien determinasi merupakan besaran yang menunjukkan besarnya variasi variabel dependen yang dapat dijelaskan oleh variable independennya. Dengan kata lain, 
koefisien determinasi ini digunakan untuk mengukur seberapa jauh variabel-variabel bebas dalam menerangkan variabel terikatnya. Nilai koefisien determinasi ditentukan dengan nilai adjusted $R$ square Hasil perhitungan regresi dapat diketahui bahwa koefisien determinasi (adjusted $R^{2}$ ) yang diperoleh sebesar 0,541 . Hal ini berarti $54,1 \%$ variasi variabel kinerja pegawai dapat dijelaskan oleh variabel kompetemsi kerja dan disiplin kerja, sedangkan sisanya sebesar $45,9 \%$ diterangkan oleh variabel lain yang tidak diajukan dalam penelitian ini.

\section{SIMPULAN DAN SARAN}

\subsection{Simpulan}

1. Hasil pengujian hipotesis telah membuktikan terdapat pengaruh antara disiplin kerja dengan kinerja karyawan. pengujian hipotesis kompetensi menunjukkan nilai $t$ hitung sebesar $-0,243$ dengan taraf signifikansi 0,720 . Taraf signifikansi tersebut lebih besar dari 0,05, yang berarti bahwa hipotesis dalam penelitian ini menerima Ho dan menolak $\mathrm{Ha}$.

2. Hasil pengujian hipotesis telah membuktikan terdapat pengaruh antara disiplin kerja dengan kinerja pegawai. Pengujian membuktikan bahwa hasil pengujian hipotesis motivasi kerja menunjukkan nilai t hitung sebesar 4,505 dengan taraf signifikansi 0,000 . Taraf signifikansi hasil sebesar 0,000 tersebut lebih kecil dari 0,05, yang berarti bahwa hipotesis dalam penelitian ini menerima $\mathrm{Ha}$ dan menolak $\mathrm{Ho}$.

\subsection{Saran}

1. Peranan pimpinan pada suatu dinas hendaknya dalam meningkatkan kinerja pegawai lebih menitikberatkan pada kompetensi dan disiplin kerja karyawannya. Dilihat dari kuesioner yang telah diisi oleh pegawai tersebut diperoleh data bahwa displin kerja sangat berpengaruh dalam kelembagaan ini, karena berdasarkan hasil penelitian dinyatakan "disiplin kerja" tidak mempunyai pengaruh positif terhadap Kinerja Pegawai" yang berarti ditolak.

2. Bagi Penelitian Selanjutnya Hasil Uji $R^{2}$ menunjukkan masih ada variabel-variabel lain yang harus diperhatikan dalam penelitian ini. Penelitian-penelitian lebih lanjut, hendaknya menambah variabel lain yang dapat mempengaruhi kinerja pegawai, karena dengan semakin baik kinerja dari pegawai maka akan berpengaruh baik juga bagi lembaga.

\section{DAFTAR PUSTAKA}

Arikunto Suharsimi, 2012, Prosedur Penulisan, Penerbit Bina Aksara, Jakarta

Dinas Koperasi,Industri dan UKM Kabupaten Lampung Selatan, 2012

Fathoni, 2006, Pelayanan Manajemen dan Persaingan Usaha, Gramedia Pustaka Utama. Jakarta

Heidjachman dan Husnan, 2003. Manajemen Sumber Daya Manusia. Penerbit Remaja Rosda Karya. Bandung.

Ma'rifah, Dewi. 2005. Pengaruh Motivasi Kerja dan Budaya Organisasi Terhadap Kinerja Pekerja Sosial pada UPTD Dinas sosial Jatim. Tesis. http/www.damandiri.com.

Prabu M. AA. Anwar. 2006. Manajemen SDM Perusahaan. Penerbit Remaja Rosda Karya. Bandung.

Peraturan Pemerintah (PP) Nomor 53 Tahun 2010, tentang Disiplin Pegawai Negeri Sipil.

Palan, R., (2007), Competency Management, Penerbit PPM, Jakarta Pusat.

Riduan \& Sunarto. 2009. Pengantar Statistika Untuk Penelitian. Penerbit Alfabeta Bandung. 
Samsudin Sadili, 2006 Manajemen Sumber Daya Manusia. Penerbit Andi Offset Yogyakarta.

Silalahi, Bennet. 2005. Corporate Culture \& Performance Appraisal. Penerbit YP. Al Hambra. Jakarta.
Sugiono.2003. Statistika untuk penelitian.Penerbit Alfabeta Bandung Supardi, Anwar, 2004, Pengukuran Efektifitas Organisasi, LPFE, UI Jakarta 